\title{
Environmental and Social Concerns of Stakeholders and Corporate Governance in Germany
}

\author{
Zahid Irshad Younas', Mamdouh Abdulaziz Saleh Al-Faryan ${ }^{2,3}$ (1) \\ ${ }^{1}$ NUST Business School, National University of Sciences and Technology (NUST), Islamabad, Pakistan \\ ${ }^{2}$ Department of Economics and Finance, Faculty of Business and Law, University of Portsmouth, Portsmouth, UK \\ ${ }^{3}$ Consultant in Economics and Finance, Riyadh, Saudi Arabia \\ Email: zahid1132_gcu@yahoo.com, Al-Faryan@hotmail.com
}

How to cite this paper: Younas, Z. I., Al-Faryan, M. A. S. (2021). Environmental and Social Concerns of Stakeholders and Corporate Governance in Germany. Theoretical Economics Letters, 11, 881-888. https://doi.org/10.4236/tel.2021.115056

Received: August 9, 2021

Accepted: September 27, 2021

Published: September 30, 2021

Copyright $\odot 2021$ by author(s) and Scientific Research Publishing Inc. This work is licensed under the Creative Commons Attribution International License (CC BY 4.0).

http://creativecommons.org/licenses/by/4.0/ (c) (i) Open Access

\begin{abstract}
This study explores the overall effects of corporate governance practices and features of board effectiveness on the environmental and social (ES) concerns of stakeholders in Germany. The research presents ES concerns through ES indices. The study uses the data of listed firms in Germany for the period 2004-2017. The study finds that overall measurement of corporate governance in firms in Germany decreases the ES concerns of stakeholders. However, when various features of corporate boards are used as measures of corporate governance, it finds that if the chairman is an ex-CEO, there are significantly higher ES concerns for stakeholders in Germany.
\end{abstract}

\section{Keywords}

Stakeholders, Corporate Governance, GMM, Stakeholder Concerns

\section{Introduction}

For the last several years, the effectiveness of corporate governance and environmental and social (ES) concerns of stakeholders has been under debate. The available literature on this issue mostly considers the principal agency problem, which is more a shareholder concern (Jensen and Meckling, 1976) than a stakeholder matter. The agency problem posits that shareholders, because of their investment, are entitled to profits and other gains, and thus corporate governance should protect the interests of shareholders only from managers (Berle and Means, 1932). To, be long term and more sustainable corporate governance sys- 
tem the existing system of corporate governance should remove the environmental and social concerns of stakeholders in a broader perspective. This is only possible if the current corporate governance system and board features of the corporate are stakeholder friendly. As the stakeholder corporate governance goes beyond the interest of shareholders and is based on the team production hypothesis (Ayuso and Argandona, 2009), thus it is presumed that unlike the shareholder model of corporate governance, stakeholder model of corporate governance is wider in its approach and can protect the wide range of stakeholder interests including their environmental and social concerns arising from corporate activities. However, empirical evidence is lacking on wider approach of corporate governance under the domain of stakeholder theory initially introduced by Freeman and Reed (1983). Under the stakeholder theory corporations are responsible for their actions towards shareholders and stakeholders both (Letza et al., 2004; Arora and Dharwadkar, 2011). According to stakeholder theory the objective of firms is being shifted from firm profitability to stakeholder well-being. With the change of scope of firm, the scope of corporate governance has also been changed from principal-agent problems to protect the interest of multiple stakeholders, which also include the environmental and social performance of the company i.e. more closely related with stakeholder concerns. Now, the effective corporate governance with the evolution of the theory of firm will be considered only that which reduces the ES concerns of stakeholders.

Further, for companies to last in the long term and to be sustainable, however, their corporate governance systems should be stakeholder oriented (Bottenberg et al., 2017; She and Michelon, 2019). This study expands the treatment of corporate governance, thus contributing to the literature, while positing that sustainability is possible only if corporate governance systems address at least the ES concerns of stakeholders.

In countries like Germany, academicians believe that corporate governance and corporate social responsibility systems of firms are stakeholder oriented. The reason behind this is the corporate governance system of Germany, which system the interests of all stakeholders (Habisch et al., 2011). However, there is very little empirical literature on the stakeholder orientation of corporate governance systems of German firms. Thus, while contributing to the literature on the corporate governance system in Germany, the study aims to examine the impact of corporate governance and features of board effectiveness: independent board structure (INBOAR), board size (BOASI), board meetings (BOAM), gender diversity of board (BOAGED, staggered structure of board (STAABOA), ownership concentration (OWNC) and if chairman is ex-CEO (CHEX), in firms in Germany on ES concerns of stakeholders. To do this, the study uses the data of listed firms in Germany for the period 2004-2017.

Previous literature about corporate governance deals only with the limited scope of agency issues and the wealth maximization of shareholders. However, 
this study broadens the scope of corporate governance, and it links overall corporate governance mechanisms and specific firm-level corporate governance mechanisms in Germany with stakeholders' ES concerns arising from firms' activities. The stakeholder model of corporate governance is not only beneficial for shareholders, but also it protects stakeholders (Kochan and Rubinstein, 2000; Letza et al., 2004). Thus, the study posits that the corporate governance systems of firms in Germany can mitigate the ES concerns of stakeholders. Based on the above stance, the following is the hypothesis of this study:

$\mathrm{H}_{1}$ : Overall corporate governance practices and different features of board effectiveness reduce stakeholders' ES concerns in Germany.

This study posits an inverse relationship between corporate governance and measurements of board effectiveness on the one hand and the ES concerns of stakeholders on the other. The findings suggest that the overall corporate governance of firms in Germany reduces stakeholders' ES concerns. However, among the different board features, if the chairman is an ex-CEO, this significantly raises the ES concerns of stakeholders.

\section{Research Methodology and Data}

The source of data to measure the stakeholders' concerns is Thomson Reuters' DataStream ESG score. In the ESG score, "E" stands for the environmental performance of the firm in such areas as reducing carbon dioxide discharge, less use of nuclear power, less wasting of water and other natural resources and effective management of the environmental supply chain. The " $\mathrm{S}$ " stands for the social performance of a firm, which includes such things as safeguarding human rights, securing the work environment for employees, adding value to the products and services, ensuring diversity in the labour force and providing equal opportunities to employees. The "G" stands for the quality of corporate governance of a firm. This score consists of a functioning corporate board along with an independent board structure. It also includes the functioning of various committees like the compensation committee and the environmental committee, the diversity of the board, transparency in accounting records, fairness in financial transactions and protection of shareholder and stakeholder rights.

This study uses the "E" and "S" scores to develop an ES index for each company. The following formula was used to measure the ES index for a given year:

$$
\text { ES index }=\frac{\text { ES performance }_{t}-\text { ES performance }_{t-1}}{\text { ES performance }_{t-1}}
$$

The span of study is from 2004 to 2017, and the data are based on yearly observations of 127 firms from manufacturing and allied sectors. Table 1 provides descriptions of the variables used in this study.

\section{Discussion of Results}

This section provides the details on descriptive and empirical results. 
Table 1. Explanation of variables.

\begin{tabular}{|c|c|c|}
\hline Variables & Definition & $\begin{array}{l}\text { Measurement } \\
\text { unit }\end{array}$ \\
\hline Stakeholder ES concern & Percentage change in ES performance of the firm & Percent \\
\hline $\begin{array}{l}\text { Corporate governance } \\
\text { (COGSC) }\end{array}$ & Quality of corporate governance practices of firm & Score \\
\hline $\begin{array}{l}\text { Independent board } \\
\text { (INBOAR) }\end{array}$ & Proportion of independent board members & Proportion \\
\hline Size of board (BOASI) & Total number of board members & Number \\
\hline $\begin{array}{l}\text { Meetings of board } \\
\text { (BOAM) }\end{array}$ & Board meetings held in a year & Number \\
\hline $\begin{array}{l}\text { Gender diversity of board } \\
\text { (BOAGED) }\end{array}$ & Percentage of women on the board & Percent \\
\hline $\begin{array}{l}\text { Staggered structure board } \\
\text { (STABOA) }\end{array}$ & $\begin{array}{l}\text { Power of shareholders to fire/retain board of } \\
\text { directors based on performance }(1=\text { true })\end{array}$ & 1,0 \\
\hline $\begin{array}{l}\text { Ownership concentration } \\
\qquad(\mathrm{OWNC})\end{array}$ & Shareholding percentage of top $5 \%$ shareholders & Percent \\
\hline $\begin{array}{l}\text { Chairman is ex-CEO } \\
\text { (CHEX) }\end{array}$ & Chairman is ex-CEO ( $1=$ true $)$ & 1,0 \\
\hline Return on assets (ROAS) & $\begin{array}{c}\text { Earnings before interest and taxes divided } \\
\text { by total assets }\end{array}$ & Percent \\
\hline Firm size (SIZE) & Total market capitalization of the firm & Dollar value \\
\hline $\begin{array}{l}\text { Dividend per share } \\
\text { (DIPS) }\end{array}$ & $\begin{array}{l}\text { Total dividend pay-outs divided } \\
\text { by outstanding shares }\end{array}$ & Percent \\
\hline Leverage (LEVE) & Percentage of total debt to total assets & Percent \\
\hline Liquidity (LIQU) & Ratio of short-term assets to current liabilities & Ratio \\
\hline Firm growth (FIRG) & Percentage of capital expenditures to total assets & Percent \\
\hline
\end{tabular}

\subsection{Descriptive Results}

Table 2 provides descriptive statistics. According to the descriptive statistics, the mean of stakeholder ES concerns is 6.1, and the standard deviation is 37.9. The minimum value of ES concerns is -64, which suggests the existence of stakeholder ES concerns in the sampled data. Moreover, descriptive statistics also show that the average value of COGSC is 36.634 , while, there is a standard deviation of 21.308, which suggests that there is much dispersion of COGSC from its average score. Similarly, the results on INBOAR show that on average almost $85 \%$ of the board of the firm is independent.

\subsection{Empirical Findings}

Table 3 provides the empirical results of this study. In these results, the dependent variable is an index of the environmental and social concerns of stakeholders (ES). In the first model, we regress the corporate governance (COGSC) with the control variables on ES. In Model 2, we regress all measures of specific 
Table 2. Results of descriptive statistics.

\begin{tabular}{ccccc}
\hline Variables & Mean & Standard deviation & Minimum & Maximum \\
\hline ES $_{\mathrm{t}-1}$ & 6.1 & 37.9 & -64 & 33.16 \\
COGSC & 36.634 & 21.308 & 3.42 & 93.29 \\
INBOAR & 84.895 & 2.277 & 67.44 & 86.95 \\
BOASI & 16.055 & 4.652 & 3 & 22 \\
BOAM & 5.598 & 1.619 & 4 & 11 \\
BOAGED & 6.998 & 7.996 & 0 & 30.77 \\
STABOA & 0.259 & 0.44 & 0 & 1 \\
OWNC & 46.62 & 29.270 & 0.260 & 89.70 \\
CHEX & 0.157 & 0.366 & 0 & 1 \\
ROAS & 54.436 & 17.972 & 22.15 & 98.49 \\
SIZE & 19740 & 24671 & 946 & 119,784 \\
DIPS & 36.241 & 18.609 & 2.8 & 96.77 \\
LEVE & 56.126 & 21.642 & 12.87 & 88.99 \\
LIQU & 1.511 & 0.649 & 0.34 & 4 \\
FIRG & 6.008 & 4.415 & 0.76 & 22.39 \\
\hline
\end{tabular}

For stakeholder ES concerns, the data on ES performance, COGSC and other control variables were obtained from the Data Stream database. Similarly, data on different board-level corporate governance mechanisms (e.g. independent board structure (INBOAR), board size (BOASI), number of board meetings (BOAM), board gender diversity (BOAGED), staggered board structure (STABOA), and chairman is ex-CEO (CHEX) are different board-level corporate governance mechanisms. Among the other variables in this table are firm-level characteristics: firm size (SIZE), leverage (LEVE), dividend per share (DIPS), liquidity position of firm (LIQU) and firm growth (FIRG).

Table 3. Results of two-step GMM.

\begin{tabular}{ccc}
\hline Variable & Model 1 & Model 2 \\
\hline ES-t-1 & $-0.175^{* * *}$ & $-0.162^{* * *}$ \\
& $(0.014)$ & $(0.047)$ \\
COGSC & $0.005^{* * *}$ & - \\
& $(0.001)$ & 0.014 \\
INBOAR & - & $(0.016)$ \\
& & 0.005 \\
BOASI & - & $(0.033)$ \\
& & -0.004 \\
BOAM & - & $(0.035)$ \\
& - & -0.001 \\
BOAGED & - & $(0.136)$ \\
& & -0.139 \\
STABOA & - & $(0.136)$
\end{tabular}




\section{Continued}

\begin{tabular}{|c|c|c|}
\hline CHEX & - & $\begin{array}{c}-0.732^{* * *} \\
(0.245)\end{array}$ \\
\hline OWNC & - & $\begin{array}{l}-0.003 \\
(0.003)\end{array}$ \\
\hline SIZE & $\begin{array}{l}6.24 \mathrm{E}-06^{* * *} \\
(1.44 \mathrm{E}-06)\end{array}$ & $\begin{array}{c}3.75 \mathrm{E}-06 \\
(2.32 \mathrm{E}-06)\end{array}$ \\
\hline LEVE & $\begin{array}{c}-0.013^{\star * \star} \\
(0.001)\end{array}$ & $\begin{array}{l}-0.004 \\
(0.004)\end{array}$ \\
\hline ROAS & $\begin{array}{l}-0.002 \\
(0.001)\end{array}$ & $\begin{array}{l}-0.006 \\
(0.005)\end{array}$ \\
\hline DIPS & $\begin{array}{c}-0.008^{\star * *} \\
(0.002)\end{array}$ & $\begin{array}{l}-0.003 \\
(0.002)\end{array}$ \\
\hline LIQU & $\begin{array}{c}0.054 \\
(0.043)\end{array}$ & $\begin{array}{c}0.324^{* * *} \\
(0.118)\end{array}$ \\
\hline FIRG & $\begin{array}{c}-0.121^{\star * *} \\
(0.009)\end{array}$ & $\begin{array}{l}-0.047 \\
(0.039)\end{array}$ \\
\hline AR (1)-p value & 0.000 & 0.000 \\
\hline $\mathrm{AR}(2)-p$ value & 0.326 & 0.371 \\
\hline Hansen's J test- $p$-value. & 0.1427 & 0.1123 \\
\hline No. of firms & 127 & 127 \\
\hline
\end{tabular}

${ }^{* *}$ represents significance at $1 \%$ level. Standard errors are in parentheses. The ES concerns the data on ES performance, COGSC and other control variables was obtained from the Data Stream data base. Similarly, data on different board level corporate governance mechanisms e.g. Independent board structure (INBOAR), board size (BOASI), number of board meetings (BOAM), board gender diversity (BOAGED), staggered board structure (STABOA), and chairman is ex-CEO (CHEX) are different board level corporate governance mechanisms. Among the other variables this table also provide the results on different firm level characteristics: firm size, (SIZE), leverage (LEVE), dividend per share (DIPS) liquidity position of firm (LIQU), firm growth (FIRG).

corporate governance simultaneously with control variables against stakeholders' ES concerns. Because of the dynamic nature of ES concerns, the study uses the two-step generalized methods of moments (GMM).

In Table 3, the results of the first model show that COGSC affects stakeholders' ES concerns significantly and positively. This means that COGSC in Germany improves the ES performance of firms. In other words, corporate governance in Germany is very effective, and as corporate governance improves, it raises the ES index of a firm. It should be noted that we assume an inverse relationship between corporate governance and the proxy of stakeholders' ES concerns (i.e. mean ES score). Thus, the results of the study are consistent with H1. Among the result on control variables of model 1, firm SIZE has a significant and positive impact on ES indices. This means that as the firm size increases the 
ES indices value of the firm rises and thus it reduces the ES concerns of the stakeholders. Similarly, in control variables of the first model, LEVE has a negative and significant impact on ES concerns, which illustrates that as the amount LEVE increases in the capital structure of the firm, the stakeholders' ES concerns also increase. Moreover, the results of the first model also confirm that as the value of DIPS increases it also reduces the ES score of the firm due to which ES concerns of the stakeholder increases. Among the other results of control variables the FIRG also decreases the ES performance of the firm which causes the increase in ES concerns of the stakeholders. However, ROAS does not show any significant effect on ES score of the firm and thus seems neutral for ES concerns of the stakeholders. Further, in the second model, the study finds an impact of different features of board-level corporate governance mechanisms on stakeholder ES concerns. In particular, it finds that if the chairman is an ex-CEO, the ES performance of the firm is affected negatively, so the ES concerns of stakeholders in Germany rise. In control variables of the second model of the study, LIQU has a significant and positive impact on ES indices of the firm, which means it improves the value of ES indices and thus reduces ES concerns of the stakeholders. The next section of the study concludes the research followed by limitations of research.

\section{Conclusion}

The results of the study are consistent with the hypothesis that corporate governance systems in Germany facilitate the mitigation of stakeholders' ES concerns. The reason for this may be that Germany is a country where a two-tier corporate governance system operates. Under this system, corporate boards are in a better position to monitor the interests of shareholders and stakeholders. From a review of different board-level features of corporate governance, the study concludes that if the chairman is an ex-CEO, it increases stakeholders' ES concerns. This happens if such a chairman uses the position against the interests of stakeholders. While contributing to the research on corporate governance and ES concerns of stakeholders, the research concludes that the influential power of a former CEO as a current chairman can raise stakeholders' ES concerns relating to the firm.

\section{Limitations of Research}

The followings are the limitations of this research:

1) The study measures the stakeholder ES concerns from ES indices, which is based on the environmental and social performance score of the firm. However, the stakeholder concerns are wider in their scope and thus demand a complete mapping of stakeholder concerns arising from the firm activities.

2) Further, it is a single-country study and its results could not be generalized for the rest of the world. Thus there is a need to increase the scope of the re- 
search from one country to more countries.

3) The time period of the study is from 2004 to 2017. However, more interesting results could be obtained by conducting research on the latest data.

\section{Conflicts of Interest}

Here are no conflicts of interest to report.

\section{References}

Arora, P., \& Dharwadkar, R. (2011). Corporate Governance and Corporate Social Responsibility (CSR): The Moderating Roles of Attainment Discrepancy and Organization Slack. Corporate Governance: An International Review, 19, 136-152. https://doi.org/10.1111/j.1467-8683.2010.00843.x

Ayuso, S., \& Argandoña, A. (2009). Responsible Corporate Governance: Towards a Stakeholder Board of Directors? Corporate Ownership \& Control, 6, 9-19. https://doi.org/10.22495/cocv6i4p1

Berle, A. A., \& Means, G. C. (1932). The Modern Corporation and Private Property. Macmillan.

Bottenberg, K., Tuschke, A., \& Flickinger, M. (2017). Corporate Governance between Shareholder and Stakeholder Orientation: Lessons from Germany. Journal of Management Inquiry, 26, 165-180. https://doi.org/10.1177/1056492616672942

Freeman, R. E., \& Reed, D. L. (1983). Stockholders and Stakeholders: A New Perspective on Corporate Governance. California Management Review, 25, 88-106. https://doi.org/10.2307/41165018

Habisch, A., Patelli, L., Pedrini, M., \& Schwartz, C. (2011). Different Talks with Different Folks: A Comparative Survey of Stakeholder Dialog in Germany, Italy, and the US. Journal of Business Ethics, 100, 381-404. https://doi.org/10.1007/s10551-010-0686-8

Jensen, M. C., \& Meckling, W. H. (1976). Theory of the Firm: Managerial Behavior, Agency Costs and Ownership Structure. Journal of Financial Economics, 3, 305-360. https://doi.org/10.1016/0304-405X(76)90026-X

Kochan, T. A., \& Rubinstein, S. A. (2000). Toward a Stakeholder Theory of the Firm: The Saturn Partnership. Organization Science, 11, 367-386. https://doi.org/10.1287/orsc.11.4.367.14601

Letza, S., Sun, X., \& Kirkbride, J. (2004). Shareholding versus Stakeholding: A Critical Review of Corporate Governance. Corporate Governance: An International Review, 12, 242-262. https://doi.org/10.1111/j.1467-8683.2004.00367.x

She, C., \& Michelon, G. (2019). Managing Stakeholder Perceptions: Organized Hypocrisy in CSR Disclosures on Facebook. Critical Perspectives on Accounting, 61, 54-76. https://doi.org/10.1016/j.cpa.2018.09.004 